\section{War and military expenditure in developing countries and their consequences for development}

\section{Paul Collier}

$\mathrm{D}$ eveloping countries have enough problems without either the waste of resources constituted by military expenditure, or the social and economic destruction brought about by warfare. I briefly review the evidence on the adverse consequences of military expenditure and warfare for development. I then turn to the question of why, since military expenditure is so costly for low-income countries, it is nevertheless so high. I show that some of the strongest empirical influences on military expenditure

Development, not deterrence, is the most effective strategy for building safe societies. reflect either neighborhood arms races, or the patronage demands of politically powerful military establishments. Both of these problems are potentially addressable. One of the other major influences on military expenditure in developing countries is internal rebellion. Where civil wars are ongoing military expenditure is greatly elevated. Further, there is evidence that governments set their defense expenditure at levels designed to deter such rebellions. I then discuss why the incidence of rebellion is so high and show that the risk of rebellion is strongly linked to economic causes - a lack of development is a major risk factor. I further discuss whether military expenditure achieves its intended effect of deterring rebellion and find that it does not. Indeed, since poor economic performance is a major risk factor, high military expenditure, by contributing to such poor performance, may inadvertently contribute to the risks that it is attempting to reduce. I conclude by suggesting that development, not deterrence, is the most effective strategy for building safe societies.

\section{How do military expenditure and war affect development?}

Both military expenditure and war retard development. This is not surprising, but there is now reasonable quantitative evidence on the scale of the effects. Military expenditure diverts government resources that could be put to better use - public services, infrastructure, or lower taxes. A joint analysis by the research departments of the World Bank and the International Monetary Fund (IMF) estimated the cost to growth and the level of income of military expenditure. ${ }^{1}$ The study found that for the average country a doubling of military expenditure reduced the growth rate for a period, eventually leading to a reduction in the level of income of 20 percent. For developing countries, the adverse effects of a given level of military expenditure on income are probably even more costly than for the global average. In developed countries such expenditure may in part be concealed routes for providing subsidies to high-tech firms, hence the term "military-industrial complex." In the poorer developing countries military equipment is imported, rather than produced domestically and so does not offer any side-benefits to technical progress.

I now turn to the costs of war. For developing countries by far the most common form of war is civil war. Whereas international warfare is often quite brief, civil wars last a The cost of civil war is considerable. During the war the growth rate is typically reduced by around 2 percent.

long time - typically around seven

years. A recent analysis finds that such wars are getting longer - they now appear to continue for around three times as long as the civil wars prior to $1980 .^{2}$ The cost of civil war is considerable. During the war the growth rate is typically reduced by around 2 percent. The losses can sometimes continue post-war: for example, people may continue to move their wealth out of the country due to perceived high risks of further conflict. Such perceptions would often not be misplaced. One model estimates that there is a 50 percent risk of conflict renewal during the first five post-war years. ${ }^{3}$ Hence, as I will discuss further below, countries can get stuck in a conflict trap. Finally, there is new evidence that the cost of a civil war spills over to the whole region in the form of reduced growth rates. ${ }^{4}$ One route for this might be increased perceptions of risk on the part of investors; another might be regional reductions in demand following from the fall in income in the country that is directly affected.

In summary, even where military expenditure is not associated with conflict, it is a drag on development. Active military conflict can lock a country into a sustained phase of economic contraction.

Why do the governments of developing countries have such high levels of military expenditure?

Developing countries have astonishing levels of poverty, yet their governments choose to devote a significant proportion of their resources to military spending which, as discussed above, actually retards growth and so accentuates that poverty. I now discuss why governments choose to use their resources in this way.

With Anke Hoeffler, I have analyzed the global pattern of military expenditure, trying to understand why some countries spend a far higher proportion of GDP on the military than do others. ${ }^{5}$ The global average for military spending is around 3.5 percent of GDP, but the ranges from virtually zero, to an astonishing 45 percent. We 
find that five factors are driving these large differences:

1. Active international warfare

2. Peacetime military budget inertia

3. Neighborhood effects (arms races)

4. Internal rebellion or civil war

5. Beneficiaries and vested interests

If a country is at international war it spends around an additional 2.5 percent of GDP on the military. If it has a civil war, it spends around an additional 1.8 percent. Countries that have a history of international war spend 1.3 percent more of GDP than those that do not.

causes war, something I discuss in the next section.

The most obvious is that high military expenditure is sometimes a response to active warfare. We find that, controlling for other factors, if a country is at international war it spends around an additional 2.5 percent of GDP on the military, while if it has a civil war, it spends around an additional 1.8 percent. Hence, one indirect explanation for military expenditure is whatever

There are also large differences in military spending among countries that are at peace. We find that one important influence on spending is if there is a past history of international war. Countries that have such a history spend around 1.3 percent of GDP more than countries that have not. Possibly this reflects an assessment of the higher risk of future conflict. However, it may also reflect inertia or political interests - once a country has built a large military, as happens during war, there are internal forces maintaining the level of government expenditure. Such persistence would not be surprising; it is indeed common in other areas of public expenditure.

To the extent that a past war raises military expenditure because of a perceived higher risk of further war, it reflects fear of neighbors, or aggressive intentions towards them. We might therefore expect that the level of military expenditure chosen by a government would, to an extent, be influenced by the level chosen by its neighbors. This is indeed what we find. That is, the average level of spending of neighboring countries significantly influences the level chosen by a government. This can be interpreted in various ways, the most obvious of which is that of a neighborhood arms race. For most countries the most serious external threat comes from their neighbors and so the appropriate level of deterrence is set by the behavior of neighbors. A different interpretation of the same phenomenon is that military expenditure is set by regional norms of behavior, in a form of emulation. If the neighbors are spending a particular share of national income on defense, then the chiefs of the military, or the minister of defense, have a relatively easy case to argue with the minister of finance, that their own country should spend approximately at the same level. Whatever the interpretation, the consequence of this regional spillover effect is that military expenditure is, in effect, a regional public bad. Each time one country raises its military expenditure there will be a ripple effect across the region. Further, as neighbors respond to the initial increase, the country that increased its military expenditure may itself respond with further increases - the classic process of an arms race. We estimate that the typical multiplier from an initial increase in spending in one country to the new neighborhood equilibrium may involve both the country and its neighbors having increased the level of spending by around three times the initial increase.

While the threat of international war is clearly one concern that might motivate military spending, for most developing country governments internal rebellion is a far more likely threat than international war. Currently, civil wars are around ten times as common as international wars.

Thus, military expenditure may

often be motivated by the desire to defend the government from the threat of rebellion. As I discuss more fully in the next section, Hoeffler and I have developed a model of the risk of civil war. We use this model to construct a predicted risk for each country, and for each time period. We then investigate whether military expenditure is related to this risk - do governments make a realistic assessment of the risk of civil war and set their military expenditure accordingly? We find that the predicted risk of civil war is significant in explaining military expenditure governments indeed anticipate the threat of rebellion and raise military expenditure in an attempt to reduce the risk. On our analysis, this precautionary spending is considerable: a government of a country with say a 30 percent risk of civil war during the coming five years would raise its spending by around 1.2 percent of GDP relative to an otherwise identical country without such a risk.

The above motivations for military expenditure have either been to fight a war or to deter it. However, these are not the only motivations for military spending. As with other forms of public expenditure, military expenditure has beneficiaries. ${ }^{6}$ In developed countries these beneficiaries are largely industrial companies that produce military hardware. Developing countries largely import such hardware and so the domestic beneficiaries are predominantly military employees. We might therefore expect that where military employees have a lot of influence over government decisions, the government will be persuaded to choose a higher level of military expenditure. This is a natural tendency - if professors were in charge of a government 
Military dictatorships have much higher military expenditure than democratic governments - an additional 2 percent of GDP. they would probably increase expenditure upon universities. This is a testable proposition because there is one readily observable circumstance in which military employees indeed have considerable influence over government decisions, namely if the government is a military dictatorship. We find that, controlling for the risks of internal and external conflict, military dictatorships have much higher military expenditure than democratic governments - an additional 2 percent of GDP. Such spending is essentially a matter of patronage rather than the purchase of efficiently delivered services. Indeed, where the military is in charge of the government, military efficiency is likely to decline since there is no independent source of scrutiny and evaluation of performance.

Some of these motivations suggest that military expenditure could be considerably lower without sacrificing interests that are worthwhile. To the extent that high spending reflects neighborhood arms races, it is potentially feasible to negotiate mutual reductions in spending. Since most developing countries receive aid inflows, it might conceivably be possible to strengthen confidence in such agreements by linking them to the conditions for aid eligibility. This might be done in the context of voluntarism: that is, a neighborhood might request the international community to assist the enforcement of its agreement. However, aid donors might also reasonably require that countries in receipt of aid inflows should avoid large levels of military expenditure. Such a use of donor conditionality could arise both to promote neighborhood arms reduction, and to discipline military governments that would otherwise indulge their own sector in excessive expenditure.

Aid and military expenditure

Three findings:

1. Aid is not significant as an explanation of the level of military expenditure.

2. Donors can do exert effective pressure.

3. Donors may have the power to reduce such spending rather than merely contain it. would therefore expect that as aid frees up government resources, the government would choose to use some of them to augment its military expenditure. Since this is evident, donors already exert pressure on aid-recipient governments to contain their military expenditure. We investigated whether these efforts have been successful, testing whether aid inadvertently raises military expenditure. Fortunately, there appears to be no leakage: aid is not significant as an explanation of the level of military expenditure. An important implication of this result is that donors appear to be able to exert effective pressure and scrutiny on governments so that their desire to spend some of the freed-up resources on the military is frustrated. In effect, donors are able to force governments to have less military expenditure than they would have liked. In turn, this suggests that donors might have the power to reduce such spending, rather than merely to contain it.

Why is the incidence of civil war so high in developing countries?

Civil war is an important impediment to development both directly and through its effects on military expenditure. It is therefore important to determine what actions are effective in conflict prevention.
Conflict prevention is usually seen as a purely political matter, but empirically the major determinants of the risk of civil war are often economic.
While this is usually seen as a

purely political matter, empirically the major determinants of the risk of civil war are often economic. Hoeffler and I find that the level of income, its rate of growth, and its structure, all have substantial effects on risk. Countries with low per capita income, slow or negative growth, and dependence upon primary commodity exports, are considerably more at risk than other countries. Thus, the relationship between conflict and development works in both directions. As well as conflict being detrimental to development, development reduces the risk of conflict. This interdependence creates a trap. Time is needed for development, but in each time period there is a risk of conflict. If a country starts from poverty, slow growth and primary commodity dependence, it is likely to lapse into conflict before it has had the time to develop its economy. In turn, the conflict can sufficiently retard development so that, even when the country returns to peace, it is likely to fall back into conflict before having had sufficient time to develop.

This is part of the rationale for aid in post-conflict countries. Fortunately, aid turns out to be particularly effective in accelerating growth during the first decade post-conflict. ${ }^{7}$ By targeting large aid inflows to post-conflict countries the international community can raise growth and hence reduce the risk of conflict renewal. ${ }^{8}$ Cumulatively, the growth raises the level of income and the economy tends to diversify, so that with luck the country can get through the phase of high risk 
(C) www.epsjournal.org.uk - Vol. 1, No. 1 (2006)

relatively quickly.

Does military expenditure reduce the risk of civil war?

A possible justification for military expenditure is that it acts as a deterrent to war. Hoeffler and I test this, investigating whether countries with high military expenditure have a reduced risk of civil war. Such a test is not straightforward. For example, as the risks of civil war mount a government is likely to increase its military expenditure. Unless this effect is taken into account, increased military spending will spuriously appear to increase the risk of war even if in fact the direction of causation is the opposite. Once due allowance is made for this problem, we find that military expenditure has no effect on the risk that a civil war will be initiated: high spending does not appear to deter rebellion. This is surprising, but it may indicate that a conventional military presence, such as soldiers in barracks, is largely ineffective in arresting the incipient stages of a rebellion. Good rural policing, or simply a good rural administration, may be more effective than an army. This is not to imply that military force has no role in conflict prevention, but rather that expansion of forces beyond those conventional in peacetime may be neither necessary nor even effective.

\section{Conclusion}

That military expenditure and conflict have adverse consequences for development is unsurprising but important. The policy challenge is to reduce them. I have suggested that substantial components of military expenditure could be reduced without jeopardizing security interests. Military expenditure does not appear to be an effective deterrent of rebellion, and, if it is reduced in a coordinated manner across a region then external security interests would be unaffected. The resources released by reduced military expenditure could be used to increase growth rates, and this in turn would gradually but effectively reduce the risk of internal conflict. Development, not military deterrence, is the best strategy for a safer society.

\section{Notes}

At the time of writing Paul Collier was at the World Bank. He is now back at Oxford University where is he a professor of economics. The findings, interpretations, and conclusions expressed in this article are entirely those of the author. They do not necessarily represent the views of the World Bank, its Executive Directors, or the countries they represent.

1. Knight, M., N. Loayaza, and D. Villanueava. 1996. “Military Spending Cuts and Economic Growth.” World Bank Policy Research Working Paper 1577. Available at http://econ.worldbank.org/files/629_wps1577.pdf.

2. Collier, P. and M. Soderbom. 2001. “On the Duration of Civil War.” World Bank Policy Research Working Paper 2681. Available at http://econ.worldbank.org/files/ 2455_wps2681.pdf.

3. Bigombe, B., P. Collier, and N. Sambanis. 2000. "Policies for Building PostConflict Peace.” Journal of African Economies Vol. 9, No. 3, pp. 323-348.

4. Murdoch, J. and T. Sandler. 2001. "Economic Growth, Civil Wars, and Spatial Spillovers.” Journal of Conflict Resolution Vol. 46, No. 1 (February).

5. Collier, P. and A. Hoeffler. 2002. "Regional Military Spillovers." Mimeo. World Bank, Washington, DC.

6. See Neil Cooper's chapter in this issue for a discussion of how the economies of conflict countries are linked into the world trade system, as well as David Gold's chapter on conflict diamonds as a case study.

7. Collier, P. 2002a. "Aid, Policy and Growth in Post- Conflict Countries." Mimeo. World Bank, Washington, D.C.

8. For a case study where this advice was not followed, see Tilman Brück's chapter on Mozambique in this issue. 